ROCZNIKI TEOLOGICZNE

Tom LXVII, zeszyt 3 - 2020

JERZY GOCKO SDB

Katedra Teologii Moralnej Spotecznej KUL

e-mail:Jerzy@Gocko.pl

DOI: https://doi.org/10.18290/rt.20673-12

\title{
KRONIKA INSTYTUTU TEOLOGII MORALNEJ KUL ZA ROK AKADEMICKI 2018/2019
}

\section{STUDENCI}

W nowym roku akademickim studia doktoranckie w Instytucie Teologii Moralnej rozpoczęli: ks. Andrzej Bogdanowicz, ks. Łukasz Głaz, ks. Artur Stefaniak.

\section{PRACE DYPLOMOWE}

\section{A. Prace doktorskie}

W Instytucie Teologii Moralnej pod kierunkiem samodzielnych pracowników naukowych sfinalizowano trzy przewody doktorskie:

Ks. Karol KonDRACIKOwSKI na wniosek Komisji Rady Wydziału KUL z dnia 19 marca 2019 r. uzyskał doktorat z teologii moralnej na podstawie rozprawy pt. Ksiadz Kazimierz Kułakowski - teolog moralista (1926-1997), Lublin 2019, ss. 336. Publiczna obrona odbyła się 11 marca 2019 r. Promotorem rozprawy był ks. dr hab. Tadeusz Zadykowicz, prof. KUL, a recenzentami ks. prof. dr hab. J. Zabielski (UKSW Warszawa) i ks. dr hab. P. Kieniewicz MIC (Warszawa).

Marcin Magnus KULA OFM na wniosek Komisji Rady Wydziału KUL z dnia 25 czerwca 2019 r. uzyskał doktorat z teologii moralnej na podstawie rozprawy pt. Dojrzatość uczuciowa jako warunek budowania wspólnoty matżeńskiej. Studium teologicznomoralne, Lublin 2019, ss. 225. Publiczna obrona odbyła się 17 czerwca 2019 r. Promotorem rozprawy był o. prof. dr hab. Andrzej Derdziuk, a recenzentami ks. dr hab. Grzegorz Chojnacki, prof. USz i ks. dr hab. Maciej Olczyk, prof. UAM. 
Ks. Łukasz Plata na wniosek Komisji Rady Wydziału KUL z dnia 30 września 2019 r. uzyskał doktorat z teologii moralnej na podstawie rozprawy pt. Dojrzatość uczuciowa $w$ formacji do kapłaństwa. Studium teologicznomoralne, Lublin 2019, ss. 266. Publiczna obrona odbyła się 30 września 2019 r. Promotorem rozprawy był o. prof. dr hab. Andrzej Derdziuk, a recenzentami ks. prof. dr hab. Alojzy Drożdż (Uniwersytet Śląski) i ks. dr hab. Andrzej Pryba, prof. UAM.

\section{B. Prace magisterskie}

Pod kierunkiem ks. prof. dr. hab. Jerzego Gocki:

Łukasz BURnICKI SDB, Dziedzictwo św. Patryka a wspótczesny kryzys katolicyzmu irlandzkiego.

Pod kierunkiem ks dr. hab. Mariana Pokrywki:

Patryk WesoŁowski, Posłannictwo rodziny chrześcijańskiej w świecie wspótczesnym na podstawie dokumentów ze Światowych Spotkań Rodzin.

Piotr SEKULSKI, Chrześcijański sens cierpienia $w$ świetle nauczania Benedykta XVI.

Liliana KuKLINOVsKa, Matżeństwo chrześcijańskie droga do świętości w świetle adhortacji papieza Franciszka „Amoris laetitia”.

Pod kierunkiem ks. dr. Jarosława Wojtkuna:

Adam ŻMUdA, Pokuta i nawrócenie w myśli biskupa Stefana Siczka.

Wojciech JoŃCZYK, Cnoty teologalne w Orędziach Benedykta XVI na Światowy Dzień Młodzieży.

Pod kierunkiem ks. dr. hab. Tadeusza Zadykowicza:

S. Alina Elżbieta SzYMurA, Postawy bt. Edmunda Bojanowskiego wobec sióstr Zgromadzenia Stużebniczek Bogarodzicy Dziewicy Niepokalanie Poczętej w świetle pism i korespondencji.

III. Z ŻYCIA INSTYTUTU

Stan personalny:

A. Katedra Teologii Moralnej Fundamentalnej i Ekumenicznej

Kierownik - Ks. dr hab. Marian Pokrywka, prof. KUL

Ks. dr hab. Sławomir Nowosad, prof. KUL

Ks. dr hab. Tadeusz Zadykowicz, prof. KUL

B. Katedra Teologii Moralnej Społecznej

Kierownik - Ks. prof. dr hab. Jerzy Gocko SDB

O. prof. dr hab. Andrzej Derdziuk OFMCap

Ks. dr Jarosław Wojtkun, adiunkt 


\section{Katedra Bioetyki Teologicznej}

Kierownik - Bp dr hab. Józef Wróbel SCJ, prof. KUL

Ks. dr Krzysztof Smykowski, adiunkt

Ks. dr Marek Kumór, adiunkt

Pracami Instytutu kierował ks. dr hab. Tadeusz Zadykowicz, prof. KUL. Ks. dr Krzysztof Smykowski pełnił funkcję sekretarza Instytutu, ks. prof. dr hab. J. Gocko - funkcję redaktora tematycznego i sekretarza czasopisma „Roczniki Teologiczne” z. 3: Teologia moralna.

4 lutego 2019 r. zmarł ks. dr hab. Krzysztof Jeżyna, długoletni pracownik Instytutu Teologii Moralnej, jego dyrektor i kierownik Katedry Teologii Moralnej Szczegółowej. Uroczystości pogrzebowe z udziałem pracowników, absolwentów i doktorantów Instytutu Teologii Moralnej odbyły się w Puławach 7 lutego 2019. Wcześnie, bo 8 listopada 2018 r., ks. Jeżyna zakończył pracę w Instytucie Teologii Moralnej i przeszedł na rentę.

\section{Awanse i nagrody:}

Ks. prof. dr hab. Jerzy Gocko został awansowany na stanowisko profesora zwyczajnego (1.10.2018).

Ks. dr Krzysztof Smykowski został zatrudniony na czas nieokreślony i awansowany na stanowisko adiunkta (1.10.2018).

Ks. dr hab. Tadeusz Zadykowicz, prof. KUL otrzymał Nagrodę indywidualną II stopnia Rektora KUL za wybitną działalność organizacyjno-społeczną i popularyzację nauki (13.12.2018).

Instytut organizował regularne spotkania wszystkich pracowników ITM, podczas których omawiano aktualne zagadnienia naukowe i organizacyjne. Świadectwem regularności i różnorodności poruszanych zagadnień są protokoły spisywane przez sekretarza ITM, ks. dr. Krzysztofa Smykowskiego.

Pracownicy Instytutu prowadzili swoje zajęcia dydaktyczne według programu przyjętego przez Radę Wydziału i zatwierdzonego przez Senat Akademicki KUL. O. prof. dr hab. Andrzej Derdziuk przebywał na rocznym urlopie naukowym.

Pracownicy Instytutu prowadzili ponadto wykłady:

Andrzej Derdziuk: Wykłady w Salwatoriańskiej Szkole Formatorek Zakonnych, Trzebinia, 15-16.01.2019, 5 godz.

Jerzy Gocko: Teologia moralna i katolicka nauka społeczna (seminarium magisterskie), WSD Towarzystwa Salezjańskiego w Krakowie, I-II semestr, 30 godz.; Teologia moralna szczegółowa (wykład), WSD Towarzystwa Salezjańskiego w Krakowie, I semestr, 30 godz., II semestr, 15 godz.

Krzysztof Smykowski: Wprowadzenie w chrześcijaństwo: życie moralne (wykład), Postulat Misyjny Księży Sercanów w Pliszczynie, I semestr, 28 godz. 
Jarosław Wojtkun: Teologia moralna ogólna (wykład), Papieski Wydział Teologiczny w Warszawie, Instytut Teologiczny w Radomiu, II semestr, 30 godz.; Teologia moralna szczegółowa (wykład), Papieski Wydział Teologiczny w Warszawie, Instytut Teologiczny w Radomiu, I semestr, 30 godz.

Tadeusz Zadykowicz: Teologia moralna szczegółowa (wykład i ćwiczenia), Archidiecezjalne Wyższe Seminarium Duchowne w Białymstoku, I-II semestr, 5 godz./tyg.

Wszyscy pracownicy samodzielni prowadzili seminaria naukowe. Ks. dr J. Wojtkun prowadził seminarium magisterskie w Wyższym Seminarium Duchownym w Radomiu.

Pracownicy Instytutu: J. Gocko, M. Pokrywka, J. Wróbel, T. Zadykowicz byli członkami komisji egzaminów licencjackich 3 czerwca 2019 r.

Instytut Teologii Moralnej był organizatorem Międzynarodowej Konferencji Naukowej pt. „Blask prawdy i miłości. Humanae vitae i Veritatis splendor dzisiaj” (Lublin, 5.12.2018).

Pracownicy Instytutu wygłosili referaty na następujących konferencjach naukowych:

Andrzej Derdziuk: Ogólnopolska Konferencja Naukowa pt. „Kościół wobec globalnej seksualizacji społeczeństw” (Poznań. 11.06.2019), referat: Ekspiacyjny wymiar pokuty sakramentalnej.

Jerzy Gocko: Konferencja naukowa pt. „Nasz stosunek do Europy” (Łeba, 8.09. 2018), referat: Chrześcijanie a oblicze Europy. Niedokończona misja; Konferencja naukowa pt. „Profilaktyka zdrowotna w kształtowaniu zdrowia człowieka - aspekty prawne, ekonomiczne, społeczne i filozoficzne" (Karpacz, 13-14.09.2018), referat: Teologiczne $i$ etyczne aspekty zdrowia i profilaktyki zdrowotnej; 36. Dni Kultury Chrześcijańskiej w Białymstoku Ku wolności wyswobodzit nas Chrystus (Klub Inteligencji Katolickiej w Białymstoku, 12.10.2018), referat: Prymas Tysiaclecia - Św. Jan Pawet II - Jasna Góra: kamienie milowe na polskich drogach wolności; Konferencja naukowa pt. „Wartościowanie życia ludzkiego. Refleksja teologicznomoralna w 50lecie encykliki „«Humanae vitae»” (Warszawa, 23.10.2018), referat: «Humanae vitae» $w$ świetle katolickiej nauki spotecznej; XII Zjazd Towarzystwa Naukowego Franciszka Salezego (Białobrzegi, 9-10.05.2019), referat: Młodzież i Unia Europejska $w$ aspekcie eklezjalno-pastoralnym i komunikat: Działalność publicystyczna TNFS.

Sławomir Nowosad: Konferencja naukowa pt. ,The Church in Poland, Iconography and John Paul II on the Human Person" (Lublin, 17.10.2018), wykład: ChurchState Relations in Poland; Konferencja naukowa pt. „St. John Paul II in His Polish Context" (Lublin, 10.01.2019), referat: St. John Paul II's Faith.

Marian Pokrywka: Ogólnopolska Konferencja Naukowa pt. „Encyklika «Humanae vitae» odpowiedź na nasze czasy" (Lublin, 17.11.2018), referat: Miłość matzeńska $w$ świetle «Humanae vitae» - program dla współczesnych matżeństw? 
Krzysztof Smykowski: IX Międzynarodowa Konferencja Interdyscyplinarna z cyklu Jeden świat - wiele kultur pt. „Polska w obliczu 100-lecia niepodległości” (Bydgoszcz, 25.10.2018), referat: Troska o środowisko naturalne przejawem mitości ojczyzny; Ogólnopolska Konferencja Naukowa z cyklu Polonia Restituta - Dekalog dla Polski w 100-lecie odzyskania niepodległości pt. „Osoba ludzka, jej prawa i obowiązki” (Poznań, 14.01. 2019), udział w dyskusji panelowej Godność osoby ludzkiej.

Jarosław Wojtkun: XI Ogólnopolska Konferencja Wolontariatu Hospicyjnego pt. „Darmo dostaliście darmo dawajcie” (Radom, 13.10.2018), wykład: Cnota bezinteresowności kapłańskiej; Konferencja naukowa pt. Wkład postugi hospicyjnej alumnów; Od „Humanae vitae” do „Amoris laetitia” (Kielce, 19.11.2018), referat: Kontynuacja myśli „Humanae vitae” $w$ „Amoris laetitia” czy propozycja nowego paradygmatu moralności?

Józef Wróbel: Ogólnopolskie Spotkanie Prawników pt. „Prawna ochrona życia” (Częstochowa, 6.10.2018), referat: Biologiczny, filozoficzny i teologiczny wymiar refleksji nad statusem dziecka poczętego; Ogólnopolskie Spotkanie Prawników pt. „Prawna ochrona życia” (Częstochowa, 6.10.2018), referat: Medyczna troska o pacjenta $w$ stanach krytycznych. Stanowisko bioetyki katolickiej; Międzynarodowa Konferencja Naukowa zorganizowana przez Association of Bioethicists in Central Europe pt. „Leben mit Risiko - Risiko im Leben. Ethische Anfragen” (Opole, 19-21.10. 2018), referat: Ethik des Risikos im Sport - metaphysische und christliche Dimension; XIX Dni Interdyscyplinarne pt. „Oświadczenie pacjenta pro futuro jako problem medyczny, etyczny, teologiczny i prawny" (Olsztyn, 23-24.10.2018), referat: Rezygnacja z terapii daremnej w oświadczeniu pro futuro. Stanowisko bioetyki katolickiej; Międzynarodowa Konferencja Naukowa pt. „Penitencjaria Apostolska - Trybunał Miłosierdzia w służbie Kościoła” (Warszawa, 7.11.2018), referat: Zamrożone ludzkie embriony $w$ kontekście sakramentu pokuty; Konferencja naukowa zorganizowana przez Uniwersyteckie Centrum Kliniczne Uniwersytetu Medycznego w Gdańsku i Duszpasterstwo Służby Zdrowia Archidiecezji Gdańskiej pt. „Życie za życie” (Gdańsk, 1.03.2019), referat: Terapia daremna z perspektywy bioetyki personalistycznej (katolickiej).

Tadeusz Zadykowicz: 36. Dni Kultury Chrześcijańskiej w Białymstoku Ku wolności wyswobodzit nas Chrystus (Klub Inteligencji Katolickiej w Białymstoku, 12.10. 2018), referat: Wszystko mi wolno, ale... Chrześcijańska wizja wolności; I Colloquium Medioznawstawa Personalistycznego im. Prof. Walerego Pisarka „Nurty personalizmu w nauce i kulturze polskiej” (Szkoła Języka i Kultury Polskiej, Lublin, 28.11.2018), referat: Argumentacja personalistyczna kwestii moralnych $w$ przekazie medialnym.

Pracownicy Instytutu pełnili następujące funkcje pozaetatowe na Uczelni:

A. Derdziuk: członek korespondent Towarzystwa Naukowego KUL; członek Rady Naukowej Instytutu Jana Pawła II KUL.

J. Gocko: redaktor tematyczny i sekretarz czasopisma „Roczniki Teologiczne” z. 3: Teologia moralna; członek korespondent Towarzystwa Naukowego KUL; egzaminator $\mathrm{z}$ teologii moralnej w ramach uzupełnień studiów teologicznych. 
S. Nowosad: dziekan Wydziału Teologii KUL; redaktor naczelny „Roczników Teologicznych"; członek Towarzystwa Naukowego KUL; członek Kapituły ds. Odznaczeń i Medali KUL; członek Komisji ds. Wdrażania Reformy 2.0; członek Podkomisji ds. Nauki KUL; członek ds. Opracowania Nowego Statutu KUL; członek Komisji Odwoławczej ds. Oceny Pracowników Naukowych; przewodniczący Komisji ds. opracowania nowego dyplomu studiów na KUL; członek Rady Naukowej CTW KUL; członek Rady Naukowej Instytutu Jana Pawła II KUL; członek Rady Programowej Uniwersytetu Otwartego KUL; członek zespołu recenzentów kwartalnika „Ethos”.

M. Pokrywka: członek współpracownik Towarzystwa Naukowego KUL.

K. Smykowski: sekretarz Instytutu Teologii Moralnej; członek (z wyboru) Rady Wydziału Teologii KUL; pełnomocnik ds. etyki badań naukowych z udziałem ludzi z ramienia Wydziału Teologii KUL; koordynator XVI Lubelskiego Festiwalu Nauki z ramienia Wydziału Teologii KUL; opiekun roku studentów teologii (kurs B).

J. Wróbel: członek korespondent Towarzystwa Naukowego KUL.

T. Zadykowicz: dyrektor Instytutu Teologii Moralnej; członek współpracownik Towarzystwa Naukowego KUL; członek Wydziałowej Komisji ds. Jakości Kształcenia; członek Wydziałowej Komisji Dyscyplinarnej; członek Komisji Dyscyplinarnej ds. Pracowników; członek Komisji ds. Promocji Wydziału Teologii KUL; członek Wydziałowej Komisji Kwalifikacyjnej do merytorycznego badania wniosków o przyznanie stypendiów doktoranckich na stacjonarnych studiach doktoranckich KUL; członek Wydziałowej Komisji Kwalifikacyjnej do merytorycznego badania wniosków o przyznanie zwiększenia stypendium doktoranckiego z dotacji podmiotowej na dofinansowanie zadań projakościowych; członek Komisji Konkursowej ds. przyznawania stypendiów naukowych dla uczestników studiów doktoranckich i młodszych pracowników naukowych.

Poza Uczelnią pracownicy Instytutu pełnili następujące funkcje:

Andrzej Derdziuk: członek Polskiej Komisji Akredytacyjnej; członek Zespołu powołanego przez Ministra Nauki i Szkolnictwa Wyższego w ramach projektu „Wsparcie dla czasopism naukowych”; przewodniczący VI Wydziału Nauk Teologicznych Lubelskiego Towarzystwa Naukowego; członek zwyczajny Stowarzyszenia Teologów Moralistów; egzaminator egzaminów jurysdykcyjnych dla młodych kapłanów w Prowincji Warszawskiej w zakresie teologii moralnej; członek Rady Naukowej czasopisma „Roczniki Teologiczne” z. 2: Teologia dogmatyczna; członek Rady Naukowej czasopisma „Roczniki Teologiczne” z. 3: Teologia moralna; członek Rady Naukowej czasopisma „Roczniki Teologiczne” z. 5: Teologia duchowości; członek zespołu recenzentów czasopisma „Collectanea Franciscana” (Rzym); członek zespołu recenzentów czasopisma „Polonia Sacra”; członek zespołu recenzentów czasopisma „Teologia i Moralność”; członek zespołu recenzentów czasopisma „Ethos”.

Jerzy Gocko: redaktor naczelny czasopisma „Seminare”; członek Zarządu Towarzystwa Naukowego Franciszka Salezego; członek Stowarzyszenia Teologów Moralistów; członek Lubelskiego Towarzystwa Naukowego; członek Sekcji Wykładowców Katolickiej Nauki Społecznej; członek komisji ds. studiów Inspektorii św. Jacka Towarzystwa Salezjańskiego w Krakowie; członek zespołu recenzentów czasopisma 
„Forum Teologiczne. Rocznik Naukowy Wydziału Teologii Uniwersytetu WarmińskoMazurskiego w Olsztynie”; członek zespołu recenzentów czasopisma „Sosnowieckie Studia Teologiczne”; członek zespołu recenzentów czasopisma „Studia Nauk Teologicznych Polskiej Akademii Nauk”; członek zespołu recenzentów czasopisma „Studia Historyczno-Teologiczne Śląska Opolskiego".

Marek Kumór: dyrektor Wydziału Duszpasterstwa Kurii Diecezjalnej w Sandomierzu; koordynator Dzieła Nowego Tysiąclecia; członek zespołu cenzorów w Diecezji Sandomierskiej; członek zwyczajny Stowarzyszenia Teologów Moralistów.

Sławomir Nowosad: członek Komitetu Naukowego AVEPRO, Watykan; członek International Institute for Hermeneutics, Toronto, Kanada; członek Catholic Universities Partnership, University of Notre Dame, USA; członek Komitetu Nauk Teologicznych PAN; członek rzeczywisty Lubelskiego Towarzystwa Naukowego; członek Rady Naukowej Konferencji Episkopatu Polski; wiceprzewodniczący Zarządu Stowarzyszenia Teologów Moralistów; członek zespołu recenzentów Narodowego Centrum Nauki; członek Komitetu Redakcyjnego czasopisma „Studia Nauk Teologicznych PAN”; członek Rady Naukowej czasopisma „Teologia i Moralność”; członek zespołu recenzentów czasopisma „Teologia i Moralność”; członek zespołu recenzentów czasopisma „Studia Theologica Varsaviensia”; członek zespołu recenzentów czasopisma „Seminare”; członek zespołu recenzentów czasopisma „Analecta Cracoviensia”; przewodniczący Diecezjalnej Komisji ds. Wyższego Seminarium Duchownego (Diecezja Zamojsko-Lubaczowska); członek diecezjalnej Komisji Teologicznej Procesu Beatyfikacyjnego ks. Błażeja Nowosada (Diecezja Zamojsko-Lubaczowska).

Marian Pokrywka: członek zwyczajny Stowarzyszenia Teologów Moralistów Polskich; członek Europejskiego Stowarzyszenia Teologów Katolickich; członek korespondent Lubelskiego Towarzystwa Naukowego; członek zwyczajny Towarzystwa Naukowego Franciszka Salezego; członek Komisji Teologii Oddziału Polskiej Akademii Nauk w Lublinie; członek Polskiego Towarzystwa Geograficznego, Oddział w Lublinie.

Krzysztof Smykowski: członek Zespołu Ekspertów Konferencji Episkopatu Polski ds. Bioetycznych; członek Lokalnej Komisji Etycznej do Spraw Doświadczeń na Zwierzętach w Lublinie; członek zwyczajny Stowarzyszenia Teologów Moralistów; członek Europejskiego Stowarzyszenia Teologów Katolickich; członek Stowarzyszenia „Bioethicists in Central Europe” (BCE); członek Rady Naukowej czasopisma „Studia Bydgoskie".

Jarosław Wojtkun: rektor Wyższego Seminarium Duchownego w Radomiu; członek zwyczajny Stowarzyszenia Teologów Moralistów; przewodniczący Synodalnej Komisji Nauki i Wychowania Katolickiego; wiceprzewodniczący Radomskiego Oddziału Polskiego Towarzystwa Teologicznego; członek Komitetu Naukowego Serii Wydawniczej Theologia Radomiensis; członek zespołu redakcyjnego kwartalnika „Zeszyty Formacji Katechetów”; członek zespołu recenzentów publikacji pod względem zgodności z nauką Kościoła w zakresie wiary i moralności przy Kurii Diecezji Radomskiej;

Józef Wróbel: biskup pomocniczy Archidiecezji Lubelskiej; przewodniczący Zespołu Ekspertów Konferencji Episkopatu Polski ds. Bioetycznych; członek Rady 
ds. Rodziny Konferencji Episkopatu Polski; członek Stowarzyszenia Teologów Moralistów; członek Rady Naukowej czasopisma „Teologia i Moralność”; członek Rady Naukowej czasopisma „Horyzonty Wychowania”; członek Rady Naukowej czasopisma „Bioetyczne Zeszyty Pediatrii”; członek Rady Naukowej czasopisma „Sympozjum”; członek Stowarzyszenia „Bioethicists in Central Europe” (BCE); członek Stowarzyszenia Teologów Moralistów „Forum Moraltheologie Mitteleuropa”; członek Towarzystwa Naukowego Franciszka Salezego; przewodniczący Kapituły Wyróżnienia „Książka Teologicznomoralna Roku” przyznawanego przez Stowarzyszenie Teologów Moralistów.

Tadeusz Zadykowicz: członek korespondent Lubelskiego Towarzystwa Naukowego; członek Europejskiego Stowarzyszenia Teologów Katolickich; członek zwyczajny Stowarzyszenia Teologów Moralistów; przewodniczący Komisji Rewizyjnej Stowarzyszenia Teologów Moralistów; członek Kapituły wyróżnienia „Książka Roku” Stowarzyszenia Teologów Moralistów; członek Towarzystwa Naukowego Franciszka Salezego; członek zespołu recenzentów czasopisma „Studia Theologica Varsaviensia”; członek zespołu recenzentów czasopisma „Teologia i Moralność”; członek zespołu recenzentów czasopisma „Scripturae lumen”; członek zespołu recenzentów czasopisma „Studia Nauk Teologicznych Polskiej Akademii Nauk”; członek zespołu recenzentów czasopisma „Studia Sandomierskie. Teologia - Filozofia - Historia”.

Pracownicy Instytutu wydali następujące monografie naukowe: A. DERDZIUK: W kręu zagadnień bioetycznych i ekologicznych. Lublin: TN KUL 2018; (wespół z T. Mantykiem), W odpowiedzi na dar krzyża. Rozważania drogi krzyżowej, wyd. 2, Lublin: Wydawnictwo Diecezjalne i Drukarnia w Sandomierzu 2018; Szata świadectwa, wyd. 2, Kraków: Wydawnictwo Alleluja 2018; Człowiek na maksa. Rzeszów: Bonus Liber 2019; Pod sufitem nieba, Lublin: Wydawnictwo Diecezjalne i Drukarnia w Sandomierzu 2019 oraz jedną pracę zbiorową: One Hundred Years of Theology at the John Paul II Catholic University of Lublin, red. S. Nowosad, J. Mastej, Lublin: Wydawnictwo KUL 2019.

Oprócz tego opublikowali 27 artykułów naukowych, 10 haseł encyklopedycznych oraz 47 recenzji wydawniczych i sprawozdań, a także oddali to druku 11 publikacji.

Pracownicy Instytutu przygotowali 4 recenzje doktorskie: M. Pokrywka - 1 (UPJPII - 1), T. Zadykowicz - 3 (UKSW - 1; KUL - 1; UWM - 1); 12 recenzji magisterskich: J. Gocko - 3, S. Nowosad - 1, M. Pokrywka - 4, K. Smykowski 1, J. Wojtkun - 2, T. Zadykowicz - 1; 16 recenzji wydawniczych: J. Gocko - 9; M. Pokrywka - 1; K. Smykowski - 1; T. Zadykowicz - 5.

Dnia 3 czerwca odbyły się egzaminy licencjackie z teologii moralnej dla studentów II roku kursu wyższego. Egzaminy zdali i otrzymali tytuł licencjata: ks. Pavel Aliaskevich, ks. Grzegorz Basara i Artur Łyczak.

Pracownicy Instytutu przygotowali materiały do opublikowania w „Rocznikach Teologicznych" z. 3: Teologia moralna za rok 2020. 